\title{
Formation of the Economic and Legal Basis for the Development of Organic Farming in Ukraine Through the Prism of European Experience and Attracting Foreign Investment
}

\author{
Daria Piddubna ${ }^{1}$, Olha Melnychuk ${ }^{2}$ Mykola Pypiak ${ }^{3}$
}

\begin{abstract}
:
The natural resources as the constituent of the natural environment and their condition are determined, which requires immediate action. The interaction of a person, his activity with the natural environment is characterized. Economic indicators, including price policy, social guarantees, protection and protection of economic activity in comparison with the international and European status are determined. The analysis of components of the environment in Ukraine is given and the legal bases for the settlement and protection of human rights and freedoms are defined. Potentially possible activities for Ukraine are outlined. The vectors of development and support from the state of Ukraine are analyzed. The direction of development of farming, which today is defined as the creation of a legal entity, with the statute, mandatory state registration, with the opening of an account in a financial institution, is determined in the framework of the current regulatory framework. Attention is drawn to the support of family forms of economic activity at the European level. In order to protect natural resources as constituents of the natural environment and components of human life, it is proposed to take measures to support and develop small and medium business entities, as well as directly owners of land plots, including land plots (shares). The prospects for the introduction of organic farming in Ukraine as an element of the state of the environment change are determined. The necessity of taking a number of economic and legal actions that will be directed not only to protect and protect the rights of citizens of Ukraine but also to meet the commitments that Ukraine has assumed through European integration will meet the generally accepted international and European requirements in the field of conducting international relations for different vectors, and also create conditions for attracting foreign investments into Ukraine.
\end{abstract}

Keywords: economic and legal basis, organic farming, European experience, foreign investment, natural resources, environment, landowners, farming, agro-chemicals and pesticides, price policy.

\section{Introduction}

The settlement of any social relations in the XXI century should be carried out with updated positions. One of them is an integrated approach, which should combine not only theoretical positions, but also practical requirements. It is precisely this situation that can be identified with respect to organic farming, which has become a common trend in the agrarian sector of the twenty-first century. In addition, such a direction of development may be explained by the state of the environment, which today, not only in Ukraine, but also in the international arena, is characterized by a negative state as a

1Ph.D. in Law, head of the Department of Civil Law Disciplines of Donetsk Law Institute of the Ministry of Internal Affairs of Ukraine.

2Doctor of Law, professor, dean of the Faculty of Management and Law of Vinnytsia National Agrarian University.

3Ph.D. in Law, Senior Lecturer of the Law Department of Vinnytsia National Agrarian University. 
whole. Such a condition is characteristic not only for one element of the environment, but also determines the problem for each component.

A rather sad phenomenon, but the most widespread, is the fact that individuals, as well as legal entities engaged in an appropriate type of economic activity, are little concerned with the preservation of the natural environment. The primary task is to get the fastest, most possible profit. At the same time, the costs to be paid in the course of economic activity are determined by the minimal costs. There are a number of issues, including the minimization of the negative impact on the natural environment. And if, first of all, nature has coped with the factors of its pollution, and the predicted natural processes restore the resources, then in the XXI century - the influence of man has become such a scale that nature can not recover itself. Man faced with a number of problematic aspects during his residence, which is connected with the state of air resources, land, water, forest resources.

\section{Economic aspects of support and development of organic farming in Ukraine taking into account international cooperation}

Taking into account the characteristics and properties of the process of organic production and organic production from the standpoint of environmental friendliness, it is necessary to determine the key actions that should be prioritized in order to change the situation. We are convinced that the priority measures should be precisely by ensuring the consideration and substantiation of economic indicators. After all, the basis of everything - lies in the economy. Understanding that not only economic benefits must be provided in the process of economic activity, it is difficult to convey to the relevant actors. Accordingly, the task arises, to carry out such measures, which combine both economic and environmental positions. Directly concerned with the conservation of the environment immediately in the process of carrying out its economic activity, can a person who has a significant spiritual development, which has a rich inner world. However, the modern world, which is determined by the characteristics of its progress, nevertheless has only degradation, and directly human actions, in many positions, have had consequences that do not provide the opportunity to even restore nature.

Thus, taking into account the practical state of the environment, human consciousness, modern human values, education, etc., believe that it is the world community to intervene in the vector of development of the planet. Its modern preservation is our future and the future of our children. It is clear that we will not achieve from each subject of economic activity to work on negative indicators. And of course it is justified and understandable. However, such clarity would be more perceived in society if it existed throughout the world. And when it happens that in one country business entities have appropriate support, assistance, pricing policy, etc., and in another country, business entities can not receive a real payment for their work, because from the side of the state as a whole and its relevant bodies carry out non-supporting measures, and the existing aspects of lobbying interests, the creation of business entities by close relatives or relatives of those who work in the civil service, non-compliance with the requirements of the activity - is not taken into account through the received unreasonable payment, motivating small wages and the need for something to exist. This 
is just a part of those issues that are available in Ukraine. And this is a really important problem, and precisely because the feasibility of conducting organic farming is justified from the point of view of the combination of ecological and economic orientation, but such an embodiment is possible only with the participation of the state in a number of areas.

So, as an example, one can identify elementary things - the price policy for agricultural raw materials and products. In particular, in Ukraine, price policy not only decreases less than abroad, but also determined by its potential decrease during direct collection of raw materials, that is, in the summer and autumn seasons, depending on the type of agricultural products. In order to realize the increased price, the subject of economic activity, especially when we talk about small and medium-sized businesses, must save the raw materials, and in a month, two or more to sell raw materials already increased pricing policy. But these individuals are not able to provide such preservation of raw materials. After all, that profit does not allow to provide the structure of the warehouses corresponding or even pay for the services of grain storage facilities. The credit policy, which should provide support for business entities, also does not provide the opportunity to take them, with certainty, the possibility of timely return, because interest rates are high enough. However, abroad such loan interest is much lower. This fact confirms the position of the necessary participation by the state in order to resolve the issue. However, it's a shame to realize that even before this, the government has established such standards and has fixed interest rates.

Realization of agrarian activity depends directly on weather conditions, which can reduce yields at times. In addition, in order to continue to highlight the situation with price policy, we note that grain traders in the Kherson region offer farmers prices three years ago, which is especially difficult for those economic entities that took loans and required to return funds (Grain traders offer farmers plundering prices, 2019). At the same time, if rains are in Ukraine, yields are lost, prices are decreasing, because in 2019, for example, barley prices are set at the level of 3100-3200 UAH per ton, and wheat $3000 \mathrm{UAH}$ per ton, then the cardinally opposite protection of agrarian producers is happening internationally. In particular, "abnormal heat in Western European countries, which lasts for 2 more weeks, has led to an increase in prices for French wheat by $2 \%$ at a time, some experts predict a significant decline in crop yields due to the heat. The September futures on flour-grinding wheat on the French stock exchange MATIF (fr Marché à terme international de France) rose by $3 € / \mathrm{t}$ to $€ 183.75 / \mathrm{t}$ or $\$ 209.54 / \mathrm{t}$. It is noted that since the beginning of the season, the EU exported 20,037 million tons of soft wheat, which is less than for the corresponding period of the previous year by $4 \%$. Imports of soft wheat amounted to 4,034 million tons, which exceeds an The July futures on soft wheat at the Chicago Mercantile Exchange (Chicago Mercantile Exchange, CME) on June 24 increased by $2 \%$, triggered by news of strong heat in the EU and heavy rainfall In the US wheat belt, which holds up harvesting, according to the NASS USDA report, as of June 24, winter wheat in the United States is collected by 15\% of the area, compared with $34 \%$ on average over the past 5 years. The number of winter wheat crops in good or excellent condition for a week decreased from $64 \%$ to $61 \%$, spring wheat - from $77 \%$ to $75 \%$. July's wheat futures in the US rose by $\$ 4.41 /$ tonne to $\$ 197.68$ / tonne for soft winter SRW wheat in Chicago; at $\$ 4.78 / \mathrm{t}$ to $\$ 171.04$ per 
tonne of hard winter wheat in Kansas City; at $\$ 2.76$ / t to $\$ 199.70$ / t on a solid spring of HRS wheat in Minneapolis" (Hot weather in Europe will adjust wheat prices, 2019). The carrying out of any activity determines the implementation of a particular process with the relevant elements. In this direction of scientific search, it is possible to define as a component of organic farming-different elements for the provision of which in the final result is sent to the business entity. That is, the receipt of the final product or raw materials should also be accompanied by economic and legal support from the state side. In this direction, it is possible to identify certain positions that are experiencing their formation in Ukraine, including through participation in grant projects with the support of the European Union.

Another similar direction can be for example to provide predictions for small and medium sized agri-enterprises of possible participation in grants from the project "Agrarian and Rural Development Program in Ukraine" in order to improve the actual and create new modern fruit processing facilities (Small producers will be awarded a grant on fruit processing, 2018). Development, and, most importantly, preservation of the environment should take place first of all through the support of the owners of the land plots, which they are given for a certain type of economic activity.

Ukraine, having a successful geographic location, is characterized by significant indicators for a variety of natural resources. First of all, it is possible to isolate this land, vegetable, animal. In order to ensure their rational use, appropriate actions should be taken to support, protect, protect, stimulate economic activity and a number of other actions, and most importantly, to bring those who are being destroyed to responsibility. What is going on and again in the first place? What is meant in Ukraine about the smoking of sturgeon and forest belts. However, nobody cares about the fact that atmospheric air in the negative indicators, the ozone layer needs immediate action, in particular, to prevent its deterioration, and most appropriate - is to ensure its improvement; a land plot including the upper fertile layer - the soil does not provide for improvement at the level of microorganisms and macroorganisms that naturally inhabit it and at the same time ensure its fertility; forest bands that ensure the existence of the plant world, various berries, mushrooms, etc., is additionally a place of residence of representatives of the animal world. And such actions take place year after year. The explanation of those persons, which is the overwhelming majority of the current agrarian corporations, indicates that this is an indication to the Cabinet of Ministers of Ukraine, and that this considerably reduces the costs of carrying out those actions on the cultivation at the proper level of land plots. In addition, even the absence of the borders of the fields to prevent flames from spreading to forest belts and adjacent plots of land, determine the irresponsible attitude of economic actors. In such cases, what kind of environmentalization can be discussed, and, accordingly, the practical situation makes us think about how, nevertheless, similar to eradicate. Its manifestation is complex, which should include economic, legal, and moral issues, include, and direct education, and even the churches should not be marginalized. After all, the destruction of nature and its elements is also a violation of biblical commandments.

Burning is directly related to vegetation, which we usually consider as weed and needs to be destroyed. However, it is quite difficult to agree with. Each plant is a component of a natural chain in the natural environment. That is how it was formed 
from the moment of creation of nature as such. Accordingly, it surely laid down some kind of appointment. And so it is, each plant is a medical aid for insects. Animals, and the person himself. The question arises: why not deal with an organic medical thing that does not destroy nature and has a positive effect on the human body. However, we are faced with a giant industry - pharmacy.

However, it is possible to note positivity in this direction. In particular, the economic indicators of dandelion growth are given: "with the minimum investment in dandelion production per hectare, $€ 5100$ and gross expenditure of $€ 3450$, in two years, you can get a gross profit of $€ 8340$ and an annual profitability of $121 \%$.... Cultivation of medicinal plants, in particular Medicinal dandelion, in small areas has a fairly high potential. Ukraine is currently actively expanding the export of herbs, which in 2017 increased by $8 \%$ compared to 2016. In particular, exports to Asia and Poland are increasing. Only last year Ukraine exported 3.7 tons of herbs for more than $\$ 7$ million. Domestic consumption is 1-1.5 thousand tons. World demand and areas under the dandelion are growing - under it 7 thousand hectares are allocated. Each year 3500 tons of leaves and 10 thousand tons of roots are produced. In the monetary equivalent, the world market for raw dandelion is estimated at $\$ 50$ million, and processing products - \$ 400 million. The price of dried raw medicinal dandelion in the EU is: on a dry sheet - $€$ 1.5-1.9 per kg, dry root - $€ 3-4$ per $\mathrm{kg}$, dry flower - $€ 1.5$ per $\mathrm{kg}$. Dandelion is used in pharmaceuticals, cosmetics, food, such as salads, tea, coffee, snacks, chewing tobacco, dandelion wine, animal feed. The expert shared that in order to achieve a profitability of $121 \%$, the minimum investment is $€ 5100$, if it concerns a plot of 1 hectare, and $€ 47850$ if the business is deployed on 5 hectares. In particular, a plot of 1 hectare requires $3 \mathrm{~kg}$ of dandelion seeds at 50 euros per kilogram. The purchase of machinery will cost $€ 4950$ : a vegetable seed drill - $€ 150$, a cultivator KRN - $€ 600$, a KTN-1 miner - $€ 600$, a tractor 25 hp. used - $€ 3000$, rotary mower 1,3 - $€ 500$, plow for T-25 - $€ 100$. For a plot of 5 hectares, $15 \mathrm{~kg}$ of seeds will be required, which will cost 750 euros (15 kg for 50 euros per kg). Purchasing equipment will cost $€ 47,100$ : 4-row pneumatic seed drill - $€ 3000$, tractor 80 hp used $€ 8000,5$ hectare irrigation system - $€ 4000$, Fingerhacke spade - $€$ 8100, Bolko digging machine - $€ 4000$, electric belt drying $€ 10$ thousand, bale trailer harvester $€ 8000$, discs $2.1 € 2000$ The yield of a dandelion is $5-8 \mathrm{c} /$ ha, if it is a dry leaf, and 16-22 c / ha, if it is a dry root (in the second year). Dandelion is sown in the early spring or in the 3rd decade of August - 1 decade of September. Fresh leaf is harvested, like vegetables, in spring, summer and autumn - up to 5 harvests on watering. The leaf for drying is harvested in the spring and summer - 2-4 harvests. Roots dig late fall" (Dandelion Business: in two years, you can earn 8,000 euros in profit, 2018).

Equally important from the side of the element of the environment and from the economic point of view is the availability of bees. It is known that precisely because of the indicated insects there is pollination of the flower and in the subsequent formation of the corresponding fruit. Without the presence of bees, the notion of any opportunity to carry out organic farming will be under great threat.

Interestingly enough is the fact that it is the shepherd who must ensure the safety of the apiary, the issue of reducing the cultivation of pesticides on the part of agricultural entities does not apply at all. However, if we turn to the cultivating mechanism, namely the time interval, then we can state that simultaneous cultivation can 
be applied to the field by several farmers in the corresponding area, the question arises: where exactly to transport the apiary and at what time.

Certain positive achievements are possible to determine the fact of payment by the farmer to beekeepers of compensation for bees, who died from poisoning with pesticides (In the Odessa region, the farmer compensated beekeepers for the loss of bee death, 2019). The situation with bees is also paid attention by the world community. It is possible to state that "The United Nations (namely, FAO) and other non-governmental organizations in the world declare:" The future of human food security depends on bees!" (Bees - death can not survive, 2019). Statistics on annual losses of bees in the world are as follows: "Germany - 20-80\%, Great Britain - 30-35\%, Italy - 20-50\%, Spain - 20-40\%, other European countries - 20-30\%, USA - 30-70\%, Canada 20-30\%, Russia 35-45\%, other Asian countries 20\%" (Bees - death can not survive, 2019). For Ukraine problematic is the poisoning of bees by various means of protection of plants and other biocides, which include: fungicides, herbicides, insecticides, acaricides and other agrochemicals; the reduction of crops, namely: the area of agricultural land -42.7 million hectares, of which the area of arable land - 32.5 million hectares $(78.4 \%$ of all agricultural lands); In arable areas, mainly crops are grown, which are of little value for beekeeping (sunflower and rape); the crop area under buckwheat decreased by $42.6 \%$ in 2028 compared to 2017; in 2019, it is projected to double less - to 40-50 thousand hectares; crops in the yard in 2017 by regions from 1 to 3 thousand hectares. It is determined that in the United States pollination agrarians pay from $\$ 50-150$ per 1 bee family. In Ukraine, this process is absent at all, or this amount ranges from 100-300 UAH per 1 bee family. Of the 100 agricultural crops that provide $90 \%$ of the world's food, more than 75 are pollinated by bees. In addition, $80 \%$ of all plant species are pollinated by insects, of which $90 \%$ are honey bees. Cost of pollinating 1 hectare of crops in the USA: almonds 700-850 dollars per 1 hectare; blueberries, strawberries, blackberries - 240-300 dollars per 1 hectare; melons - 150-240 dollars per 1 hectare; apple, plum - 200-240 dollars per 1 hectare; Cherry - \$280-350 per 1 hectare; raspberries - 500-600 dollars per 1 ha. Pollination of almonds alone costs farmers $\$ 280$ million. However, due to full crosspollination, they collect 1 million tons of nuts worth more than $\$ 5$ billion. In Turkey, agrarians produce polluted products at 8.4 billion euros. Total beekeeping income from beekeepers - EUR 563 million. In Uzbekistan pollination by bees has raised the yield of apricots by almost 6 times, plums - by 11 times, cherries - by 22.5 times, cherries by 26.4 times. Pumpkins, melons, watermelons yields $60 \%$. The losses from non-pollinating only apple orchards amount to 50-100 thousand UAH / ha Pollination costs - 1-2 thousand UAH / ha" (Bees - death can not survive, 2019).

The report highlights the "California jury trial obliged the manufacturer of agrochemicals to pay a colossal amount of compensation to a married couple who fell ill with cancer." The man and woman convinced the jury that their illness was caused by the prolonged use of the means for controlling weeds, and the producer did not warn them. about such risks: the drug that can cause cancer, is 6 parts of the Ukrainian market of herbicides" (Americans sentenced to a billion-dollar compensation for the manufacturer of herbicides popular in Ukraine, 2019). It should be noted that the specified herbicide is allowed on the markets of the European Union only until 2022, that is, according to general rules, Ukraine will also have the task of abandoning its use, 
but so it is expedient to wait until 2022 and further contaminate Ukrainian black earth. It is also determined that the specified herbicide causes such a disease as autistic in its offspring (Because of the guilt of Monsanto, every second child will be autistic by 2025 , 2019).

Based on events with bees, the Ministry of Agrarian Policy and Food of Ukraine reduced the period of approval of unscheduled inspections by the inspectors of the State Committee for Proprietary Affairs in case of poisoning of bees from several weeks to one day. Further approvals will be provided within a few hours. In the case of poisoning of bees with pesticides, the territorial departments of the State Committee for Supervision of Civil Service send electronic requests to the Ministry of Agrarian Policy, while informing the central apparatus of the service. In parallel, the official documents are in the ministry all stages of approval. This provides an opportunity to implement one of the directions of the ministry, aimed at protecting the environment from the misuse of plant protection products.

In the future it is advisable to direct the soil condition in Ukraine. In particular, "annually in Ukraine, due to erosion, about 300-600 million tons of soil is lost due to the degradation of the processes of degradation, the yield can decrease to $50 \%$, and losses from shortage of products may amount to over 20 billion UAH per year ... the area of degraded and unproductive arable land in Ukraine exceeds $20 \%$ of arable land. "Why does the land degrade? In classic examples of crop organization, it is recommended to form crop rotation from 5 crops, as well as 3-5 years to leave the field under pairs there's nothing to be planted there and, if the average term of the field lease in 7 years, such a luxury farmers can not afford. Another land and attitude relevant.None owner will not kill his land as it kills the tenant ... In the lease Top 10 agroholdings account for about 3 million hectares of land. The largest agroholdings themselves have long been not Ukrainian companies, and some of them have 100\% foreign capital" (The degradation of soils is threatened by the loss of half of the crop yields, 2019).

Some positive direction can be determined by the fact that the Verkhovna Rada of Ukraine adopted a "no-visa" for imported agricultural machinery, but in the overwhelming majority this technique has a considerable volume, which, according to the structure and density of Ukrainian soils, destroys them through its weight indicators . So far, at the level of the bill, the following proposal is highlighted, which is substantiated by the implementation of legislative acts of the European Union in the field of technical regulation No. 10183 dated 25.03. 2019. It is also possible to state the draft: "Draft Law 10183 amends 15 laws of Ukraine and concerns a number of issues related to the certification and conformity assessment procedure, scope, activities of conformity assessment bodies and technical services that will have an impact on agricultural The approval of the law allows: 1) to recognize the results of the assessment of the conformity of tractors manufactured in other countries, if the requirements are in line with Ukrainian; 2) to sign agreements at the level of the state on recognition of the results of conformity assessment; 3) at the legislative level, to consolidate the right of approval bodies and technical services to enter into agreements on recognition of the results" (The VRU has adopted a "no-visa" for imported agricultural machinery, 2019).

The question of state support, economic substantiation for economic entities in the agrarian sector can be explained by the existing indicators for the export of various 
types of products and raw materials to international markets, as well as the beginning of activities on updated objects of public relations. In particular, it is determined that Ukraine in 2018 sent export of agricultural products to Japan for more than \$ 112 million, which is $32 \%$ more than in the previous year (Ukraine increases agroexport to Japan, 2019).

Together with some positive directions for Ukraine in the field of organic farming, a number of promising positions, which at that time are realized at the level of the countries of the European Union, remain outstanding. In particular, in Poland, the Citronex group invests around 60 million euros by the end of 2020 to build one of the most modern organic greenhouses in Europe, based on the production of tomatoes, land plots are plotted with an area of 20 hectares, the creation of new jobs is determined by 250 seats (In Poland, one of the most modern organic greenhouses in Europe will be built, 2019). The favorable investment climate is a key to development.

In order to ensure the development of the agrarian trend of Ukraine in accordance with world requirements, an analysis of dynamics and trends of development should be constantly conducted. It should be borne in mind that the main strategy of the United Nations for the next 10 years is determined by family farms. In particular, family farms, especially in developing countries, came to the forefront of the Food and Agriculture Organization (FAO) and the International Fund for Agricultural Development (IFAD) ... Family farms account for more than $90 \%$ of all farms in the world and produce $80 \%$ They are key to sustainable development, including the elimination of hunger and all forms of malnutrition ... The Decade of Family Farms aims to create a supportive environment that It strengthens their positions and maximizes their contribution to global food security and nutrition, as well as a healthy and sustainable future. The global plan of action for 2019-2028 emphasizes the need to extend, among other things, the access of family farms to social protection mechanisms , finance, markets, training, and revenue opportunities. ... The Global Plan of Action describes in detail the specific steps taken to address interrelated issues. These measures include: the development and implementation of favorable policy conditions (including a comprehensive and coherent policy, investment and institutional framework) to support family farms at the local, national and international levels; supporting rural youth and women through providing them with access to productive assets, natural resources, information, education, markets and participation in policy development processes; strengthening family-based farmer organizations and their ability to generate knowledge and associate local (traditional) knowledge with new solutions; improving the livelihoods of family farms and increasing their resilience to multiple dangers, providing them with access to basic social and economic services, and promoting and promoting diversification of production in order to reduce risks and increase economic returns; improving the stability of family farms for food-resilient climate change and access to them, responsible management and use of land, water and other natural resources" (The main strategy of the UN for the next 10 years is the family farms, 2019).

Instead of taking into account international experience and ensuring the provision of national legislation, Ukraine has another problem - the treatment of sheep breeders to take urgent measures to save them, since without government intervention it is difficult to maintain a positive profitability of sheep - due to the excessive cost of feed 
and low prices for the sale of manufactured goods; without the adoption of the law on the development of sheep breeding in the mountainous regions of the Carpathians (Farmers are asking the authorities to help save the sheep, 2019). Accordingly, if the state interferes with economic activity, it accordingly has to guarantee their existence, if all the same happens in one direction without interaction, we will continue to destroy the branches of agrarian production, the destruction of rural areas, the lack of food security of the country, the loss of natural resources and many other negative indicators. However, if to analyze the intervention of the state in the main issue - price policy and taking into account the land reform, which determined the owner of the land, enough justification is such an intervention in the veiled way of selecting land holdings, because owners will leave them, or take leasing, motivating the impossibility to carry out activities on it and lack of profit.

\section{The legal basis of the agrarian sector, including the provision of the development of organic farming and ensuring the possibility of attracting foreign investment}

Any social relations that are formed by practical life require their legal regulation to ensure clarity and the absence of disputes over their settlement. Investigating the previously different social relations that arise during organic farming (Piddubna D.S., 2019; Piddubna D.S., 2018), it is possible to determine that with the development of social relations also undergo changes. In the aspect of considering the aspects of the agrarian market, scientists are determined (Yermolenko V.M., 2019; Karakash I.I., 2019; Marchenko Sv. I., 2019) and others. Immediately the issue of the economic-legal mechanism in the agrarian sector and the environmental friendliness of natural resources were highlighted in the writings of scientists (Hetman A.P., 2019; Kostenko V.O., 2015; Romanko Sv. M., 2008; Shulha M.V., 2019) and others. However, it is currently relevant and needs constant doctrinal attention, the position of legal and economic and social study of organic farming due to the variability of the object and subject structure of modern practical life.

XXI century - a period of technologies, innovations, and most importantly market relations. The activity and success of any business entity is the ability to maximize the consideration of modern needs, global trends, changes, and taking into account the environmentalization of economic activity, since this direction is determined by the crisis on a global scale. In the agrarian sector, such environmentalization has begun through the introduction, support of organic farming, the transition to alternative types of energy and a number of other actions. Ukraine has focused on the European community. Accordingly, a number of obligations arise in front of the country. It is worth recognizing that such obligations and variability not only relate directly to economic entities, but also directly to public authorities, local governments, including newly formed united territorial communities. Thus, it is urgent to ensure from the side of the state the position of "politics and business - different structures", and for the purpose of onehundred percent implementation, to be envisaged in the Law of Ukraine "On Civil Service" (Verkhovna Rada of Ukraine, 2015) the addition of Article 3 of the Law part 5 of the following content: close relatives of persons indicated in accordance with Part 2 
and Part 3 of Art. 3 of the Law do not have the right to carry out any kind of economic activity, except for management, which arises in connection with the receipt of the inheritance.

In addition, each type of activity is regulated by separate legal acts, which, for the same application of legal norms, must also be amended by an appropriate article of the same content.

Guided by the Law of Ukraine "On the Production and Circulation of Organic Agricultural Products and Raw Materials" (Verkhovna Rada of Ukraine, 2013), it is possible to determine its regulation of relations in the sphere of production and circulation of organic products (raw materials) and distribution to economic entities that carry out economic activity in this sphere and on organic products (raw materials) received in accordance with the requirements of the Law. Among the legislation applied in the field of production and sale of organic raw materials are determined by the Constitution of Ukraine, the Law of Ukraine "On Environmental Protection", other laws of Ukraine, international treaties of Ukraine, the consent to be bound by the Verkhovna Rada of Ukraine, other normative and legal acts issued in accordance with them. This interpretation is in line with the changes since 2015, since the very first version of the Law contained references to other codes and detailed legislative acts.

However, as of August 2, 2019, an updated regulatory legal act in the field of organic energy comes into force - the Law of Ukraine "On Basic Principles and Requirements for Organic Production, Turning and Marking of Organic Products" (Verkhovna Rada of Ukraine, 2018). According to its normative legal provisions a significant list of terms is defined, and Part 2 of Article 1 states that "other terms are used in this Law in the meanings defined in the laws of Ukraine" On basic principles and requirements for the safety and quality of food products " "On aquaculture", "On veterinary medicine", "On state control over observance of legislation on food products, feed, animal by-products, animal health and welfare" and other legislative acts of Ukraine" (Verkhovna Rada of Ukraine, 2018). Regarding the scope of the Law: "regulates relations in the field of organic production, circulation and labeling of organic products that are produced, in circulation, imported into or exported from the customs territory of Ukraine under the customs regime of export. This Law shall not apply to production and circulation. products intended for own consumption, perfumery and cosmetic products and medicines, products of hunting and fishing, extracted from the environment" (Verkhovna Rada of Ukraine, 2018). Article 3 of the Law defines legislation in the field of organic production, circulation and labeling of organic products, in particular: "The relations in the field of organic production, circulation and marking of organic products in Ukraine are regulated by this Law and issued in accordance with it by regulations, safety legislation and certain indicators of food quality, state control over compliance with legislation on food, feed, animal by-products, animal health and welfare On plant quarantine, plant protection, seed production and seedlings, veterinary medicine, beekeeping, aquaculture, viticulture and winemaking, the protection and use of flora and fauna, as well as land, forest, ecological and other special legislation, which regulates relations in this sphere" (Verkhovna Rada of Ukraine, 2018). Thus, for today we have not a simplified and transparent normative legal act in the field of organic 
matter, but accumulated by blanket rules of law, which greatly complicates the implementation of this type of production.

At the same time, representatives of the Ministry of Agrarian Policy and Food of Ukraine announce the revision of the legal field of organic management, directly at the state-private level and awareness of Ukrainian consumers about organic products (The Ministry of Agrarian Policy works on the legal basis of the organic sector, 2019).

The Eurointegration direction of Ukraine makes it necessary to take into account the norms of European legislation. In particular, in accordance with Council Regulation (EC) No 834/2007 of 28 June 2007 concerning organic production and labeling of organic products and repealing Regulation (EEC) No 2092/91 (Council Regulation (EC) No 834/2007, 2007), understanding organic production as a "holistic food management and production system that combines best practices in terms of environmental conservation, biodiversity, conservation, the application of high standards of proper maintenance (welfare) of animals and the production method that meets a certain requirements for products made using substances and processes of natural origin" (Council Regulation (EC) No 834/2007, 2007). Also, the understanding of equivalence found in the contents of the Resolution, as well as the consolidation of the issue of the import of such goods, should take place through the provision of supporting documents, between which the certificate is determined. Thus, we can state that if it is a case in this case about the export of raw materials or products, as organic to European countries, the business entity must receive an appropriate certificate in accordance with the requirements, which will confirm the organicity of products or raw materials. However, it raises the question of consolidating the understanding of organic production at the national level of Ukraine, in particular as "certified activities related to the production of agricultural products (including all stages of the process, namely primary production (including harvesting), preparation, processing, mixing and associated with this procedure, filling, packaging, processing, recovery and other changes in the state of products), which is carried out in compliance with the requirements of legislation in the field of organic production, circulation and marking organic products" (Verkhovna Rada of Ukraine, 2018). This definition defines organic production as a type of economic activity, since it is directly laid down that this is the most certified activity, but in no way determines its environmental friendliness, and does not see national interest, conservation of natural resources in line with European requirements in the implementation of international norms of law. Taking into account the situation in Ukraine, the state of the environment, medical indicators on morbidity and mortality, taking into account the extinction of villages, etc., it would be more appropriate to identify organic production not only as certified activity, but also to provide ecologically pure management for the products (raw materials) of domestic consumption.

In accordance with Commission Regulation (EC) No 889/2008 of 5 September 2008, detailed rules on organic production, labeling and control for the implementation of Council Regulation (EC) No 834/2007 concerning organic production and labeling of organic products (Detailed rules) we can determine a certain detail about the components of organic production, which includes aquaculture, determines the need not to use pesticides, determine the issues of planting and livestock, and a number of other positions, but it is interesting that the entire procedure of cultivation, possible 
consequences, procedures for use and etc., is clearly regulated at the level of the Regulation, and according to the national legislation, such positions are not seen. In the overwhelming majority, such positions are not always reflected at the level of by-laws within the framework of sanitary and epidemiological norms, on the grounds that such positions are the direction of agricultural and biological science. However, such an approach is incorrect, because it does not take into account the real situation and the possibility of implementing one or another kind of management, and the rules of law for it and become "dead", because they are not able to be implemented in practice, since it is possible to characterize them as abstract.

Having noted certain elements at the beginning of the study and having analyzed the relevant acts of the European Union, it is possible to state a number of necessary actions. In particular, at the state level, all measures envisaged for each component of agricultural activity, which are clearly stated at the level of the Directives, Decisions, etc., are implemented at the state level, which is carried out by the State party itself. In order to create a single informative field in order to ensure a unified European understanding, it is necessary to take into account the timeframe existing under the relevant normative and legal acts, since at present, at the level of national legislation of Ukraine, the relevant term may have in mind one vector of understanding, and at the level of the European Union, the following word may have a different interpretation or not be foreseen at all, accordingly, individuals will not be able to understand what exactly we are trying to bring to their attention. Consequence - non-compliance with requirements, misinterpretation, non-execution or non-fulfillment of contracts, there is no international process, including European trade, and consequently - the receipt of appropriate losses, unsuitability of products (raw materials), etc.

Legal support - it should always be a set of appropriate actions. Such actions should take into account undoubtedly practical requirements, economic substantiation, and their combination and interaction is possible due to the presence of citizens of the appropriate level of thinking, consciousness, and culture. It is possible to note that, with the support of the European Union in Ukraine, various projects were started to develop in order to provide an educational direction. In particular, the Ministry of Agrarian Policy and Food together with the European Union project SAFRI implements the information company "State support for the development of farms and agricultural service cooperatives in 2019", according to which it is planned to inform about: "state support to farmers of advisory services, about united territorial communities, farmers' associations and regional departments of the agro-industrial complex from all over Ukraine, which will continue to distribute information directly among farmers on the ground" (The Ministry of Agrarian Policy together with the EU Project is conducting a broad information campaign on state support to farmers, 2019). However, as it is seen from the Project, farmers, associations, ie large agricultural producers, are left to study, outside the remaining small and medium-sized business entities in the agrarian sector, as well as owners of land plots, including land plots (shares). In addition, the subjects of education are subjected to representatives of village, settlement and united territorial communities, which organize the work of information mobile centers in the oblasts. However, such a design raises a number of issues, since it is a question of representatives of village, settlement and united territorial communities, and information centers should be created in the areas of how 
different administrative and territorial units are to be interrelated. It is also interesting that according to the program, which is implemented through the European Union, it is determined that the development of tools for attracting small producers and family farms to the organized agricultural market, creation of favorable conditions for production and trade for them, and also readiness to finance the development and the implementation of the State Agrarian Register of Ukraine and the introduction of an efficient and transparent system of distribution of public funds. The Ministry of Agrarian Policy and Food of Ukraine made significant positions on the state financial support for the development of farming in 2019, namely: "partial compensation of the cost of purchased agricultural machinery and equipment of domestic production $(25 \%+15 \%$ of compensation), partial compensation of the cost of seeds of agricultural plants domestic production; budget subsidies (1 hectare for newly created FG and budget subsidy for 1 member of the newly created FG); provision of interest-free loans for turning second basis and cheaper loans, compensation costs related to the granted agricultural advisory services, government financial support for the development of viticulture, horticulture and hop, as well as financial support in the field of animal" (The Ministry of Agrarian Policy together with the EU Project is conducting a broad information campaign on state support to farmers, 2019). However, a number of questions arise, and precisely why it is the farming industry, because today's farming sector in Ukraine is a legal entity that registers and opens an account with a financial institution and is located on the appropriate tax system. Secondly, the funds put up and the budget where they arise are either international loans that are sooner or later needed to be repaid or funds received through various taxes from citizens of Ukraine, sole proprietors and legal entities. The question arises of the appropriateness of such state financial support, and as a consequence for citizens - an increase in tax rates. Therefore, it should become a step, at the same time, at the state level to define the agrarian sphere not as a subsidy industry, but as a type of management that is carried out at its own risk by the relevant entity. Secondly, to make an urgent distinction between activities in the agrarian sector and policy and close relatives. Thirdly, to remove any customs and legal barriers to free trade with any country in the world. Additionally, for every inhabitant of the country, to provide information on activities in the agrarian sector, the feasibility of its implementation, natural or organic in order to immediately restore the village and settlement areas, because the specified administrative-territorial units - the basis of any country, the basis for ensuring food security ; biological, genetic and biodiversity in general (in accordance with current needs and the state of the environment), and, as a result of the integrated impact, the national security of the country.

An updated regulatory act on organic matter in Ukraine does not see a mechanism for any question about informing the public that can be identified as a gaps. Because, due to information, popularization of a particular direction, etc., it is possible to achieve changes in consciousness, change in attitudes, possible so to determine - to make a modern trend that will affect the improvement of the natural environment.

Confirmation of the need for informing and its expediency are the actions of the European Union, which are aimed at developing relevant informative booklets in different directions. In particular, the EU project "Supplementing the Ministry of Ecology and Natural Resources of Ukraine with the implementation of the Sector 
Budget Support" Quality of the air: a brief description of the EU Directives and timetable for their implementation (EU project, 2015); Developed with the support of the Federal Ministry of Food and Agriculture of Germany a practical guide for an organic exporter to the EU (Practical guide to the organic exporter to the EU.2, 2017), which reveals the issue of tracking organic export products, the issuance of a certificate of inspection for export and logistics of various types of transport. The question arises about which certification is determined at the level of national legislation, if those certificates do not take into account positions for their recognition at the European level.

First of all it is necessary to start with the formation of consciousness by placing various information stands, billboards, posters, launching of environmental videos, flyers, creating environmental programs on radio and television channels, as well as taking into account and adding administrative resources, in particular the relevant structures of the National Police of Ukraine, which have to fulfill one hundred percent of their functional duties. With regard to denunciations, fines, etc., as defined in Germany, taking into account the mentality of Ukrainian citizens, we will have a lot of questions about defamation, which is why the initial step should be an informative environmental policy.

Today, among the elements of government support for the agrarian sector, it is possible to bring a position on the withdrawal of small farmers in a separate tax group (The Ministry of Agrarian Policy believes that small farmers should be brought under a separate taxation group, 2019). Taxation issues in Ukraine do not support business development, but the direction of obtaining resources to fill the corresponding budgets. Such a policy usually does not correspond to market relations and determines the nonreceipt of foreign investments into Ukraine, due to the unprofitability of its activities, and especially when it comes to the implementation of registration in the territory of Ukraine. The above is one example of managing, and such positions can lead to a fairly significant amount. In addition, it is worth noting the constant change in the name of the fiscal service in the tax area and vice versa, with the impression that the mechanisms to simplify the procedure for doing business, including in the agrarian sector, depend on it. However, for such renamations, there is a need to change the basic documents of the relevant service-bodies, and, accordingly, public funds are spent in an unclear direction.

Given the significant emigration of young people and able-bodied people for Ukraine, the state faces an urgent task of changing the economic and social situation in the country on a comprehensive scale. For example, it is possible to bring about the actions of Poland, as a country that also faced a similar, but to this day, it was this country that became the basis for the emigration of Ukrainians. Starting from July 1, 2019, the Polish leadership plans to implement a number of projects that include: Polish citizens, as well as foreigners living in Poland, will be given the opportunity to get help for a child regardless of the financial situation of the family; tax exemption is planned for all Poles working up to 26 years old; It is envisaged to introduce pension payments every year to pensioners (Poland abolish income tax for young people and will support Ukrainian families, 2019). For Ukraine, the lack of any program for youth, urban and rural and settlement, the difficulty of finding a job, low wages, social disruption, and economic plan in the country are motivating to leave abroad. In order to change the situation, it is necessary to change the state policy urgently in support of the younger 
generation, to make real wages, to reduce the tax burden, to simplify the business conditions, to simplify the system of requirements for education, etc. All these actions must be accompanied by the appropriate legal regulation.

Within the context of changing the situation regarding the control of the use of pesticides and agrochemicals; providing information about the placement of apiaries; control over the presence of dry or cracked winds, heavy rain of trees; ensuring the fight on the road with unreasonable arson, taking into account European experience (The EU has published rules for the use of unmanned vehicles, which will take effect in a year, $2019)$ it is possible to introduce a legal basis for the use of drones in Ukraine.

The following principle should be the basis for the agrarian sector, including the development of organic farming on the way to preservation and improvement of the natural environment: state support to ensure maximum economic and social effect for actors in the agrarian sector. Finally, it is quite positive from the representatives of the Ministry of Agrarian Policy and Food of Ukraine that the number of farms is over 33 thousand, and the production of agricultural products within private peasant farms is estimated at 4 million (State support should have the maximum economic and social impact, 2019). It is this fact that determines the direction of action by adopting the Concept for the Development of Farmers and Agricultural Cooperatives for 2018-2020, including through the creation and deployment of mobile information centers to support the development of farming, but the support of farming is determined. It is necessary to already understand that farming and private peasant farming are different legal regimes of economic activity and the formation of mass farming in Ukraine is a false step that will create exceptionally large agricultural holdings, destroy villages and settlements, and, accordingly, the basis of the country and endangers the issue of food safety, not to mention the preservation of nature.

\section{Conclusions}

As a result of scientific research through the prism of taking into account practical substantiation, the following conclusions are reached:

1. The settlement of emerging social relations in the twenty-first century should take place on an integrated and systematic basis.

2. Taking into account the international and European experience in providing support to actors in the agrarian sector from weather conditions, it is also determined for Ukraine that such support may also be introduced, which may consist in the legal regulation of a number of positions, in particular regarding payment of land fees when it comes to owners of land plots, including land plots (shares), and if created by legal entities - annual exemption from taxation for all types of taxes.

3. In Ukraine, price policy is not only less than in a foreign country, but also determined by its potential decrease during direct collection of raw materials, that is, in the summer and autumn seasons, depending on the type of agricultural products. Instead, abroad, in case of a decrease in price policy, the state, in order to protect its economic agents, interferes in the formation of price policy, including through the implementation of public procurement. 
4. To provide state support for informing about grant projects and necessary actions for participation in them.

5. For the owners of land plots who are more interested in ensuring the implementation of a combination of economic and environmental trends during their activities, provision should also be made for training grants; to provide simplified mechanisms for the establishment of a unified management, in particular through association in cooperatives, simplification of registration mechanisms, and most importantly - to create support through the mechanism of taxation and ensuring the possibility of international trade. The step towards ensuring international trade should not only be the creation of opportunities for a business entity to transport raw materials or products across borders to European countries, but also to maximally facilitate the entry into the Ukrainian market of various international actors that will independently carry out procurement on the Ukrainian territory activity directly from manufacturers, thereby increasing profits, since such a person will disappear as a purchaser.

6. The analyzed state programs determine the confusion with the subject structure, which is why it is necessary to clearly identify that in accordance with the current regulatory framework of Ukraine: an entrepreneur and a farmer are different legal statuses of the person of activity. Depending on the status of activities, taxes will be paid in different ways and economic activities will be carried out in general. In addition, the main question arises - where the owners of land plots, including land plots (shares), which independently carry out economic activity on them, arises. Also, where those persons who received plots of land for gardening, gardening or private farming. Development, and, most importantly, preservation of the environment should take place first of all through the support of the owners of the land plots, which they are given for a certain type of economic activity.

7. Issues concerning the burning of stubble and vegetation residues have been identified, the absence of segregation according to the subject structure and the question of liability in the event of non-compliance with regulatory requirements have been characterized. It is necessary to determine that the burning of vegetation in forest bands creates a threat to the destruction of vegetation, which by its natural properties is a medicinal product, and may accordingly be the object of pharmaceutical relations. Medicinal plants are a potential element of development for Ukraine.

8. The analysis of the condition of bees in Ukraine determines the need for radical and urgent actions to protect them. After all, bees are an element of the environment, as well as an element that provides pollination of vegetation. In its absence, it is impossible to carry out either organic or ecological pure management. The monument for beekeepers, the question of responsibility of subjects using agrochemicals and pesticides, ignoring the requirements of the Law of Ukraine "On beekeeping" in the part of the notification on field processing, attention was paid to the loss of bees at the international level and the economic side of the use of bees in pollination process; attention was drawn to the existing facts about the possibility of settling certain pesticides in land resources, water resources, as well as field flowers and trees; the measures taken to ban the use of a number of pesticides in the European Union have been noted; attention was drawn to the facts of the disease of people from the use of genetically modified organisms, as well as on non coexistence with organic products; the changes were made regarding the 
period of the inspection of the consequences of death of bees from one week to one week.

9. The agrarian sector in Ukraine has significant figures for European and international trade, and is determined by its further expansion, which determines and fulfills a number of requirements. At the international level, programs are being set up to stimulate family farms through the development and implementation of favorable policy conditions (including a comprehensive and coherent policy, investment and institutional framework) to support family farms at the local, national and international levels; supporting rural youth and women through providing them with access to productive assets, natural resources, information, education, markets and participation in policy development processes; strengthening family-based farmer organizations and their ability to generate knowledge and associate local (traditional) knowledge with new solutions; improving the livelihoods of family farms and increasing their resilience to multiple dangers, providing them with access to basic social and economic services, and promoting and promoting diversification of production in order to reduce risks and increase economic returns; improving the stability of family farms for food-resilient climate change and access to them, responsible management and use of land, water and other natural resources.

10. It is urgent for Ukraine to ensure from the side of the state the position of "politics and business - different structures", and for the purpose of one hundred percent implementation, to provide in the Law of Ukraine "On Civil Service" the addition of Article 3 of the Law to Part 5 of the following content: close relatives of persons indicated respectively to Part 2 and Part 3 of Art. 3 of the Law do not have the right to carry out any kind of economic activity, except for management, which arises in connection with the receipt of the inheritance. Each type of activity is regulated by separate normative legal acts, which, for the same application of legal norms, should also be amended by a corresponding article of the same content.

11. A special regulatory act, which comes into force on August 2, 2019, has a number of blanket norms in Ukraine and is characterized by the accumulation of terminological use by referring to other normative legal acts. In addition, the European integration direction of Ukraine determines the consideration of a number of Directives and Conventions of the European Union, which still have to be implemented in Ukraine, and the national legislation is brought into conformity. In particular, the EU legal framework has clearly defined elements and appropriate detail, the national legislation of Ukraine is characterized by an incomplete legal settlement mechanism, which in a legislative act determines the need for the development of a number of subordinate legal acts, and often they do not define the necessary issues for implementation activities. An additional problem is that often developed norms do not relate to practical requirements, which in the future promotes the creation of "dead" rules, which can not be used in practice, since they are abstract. The next step should be to bring the terms at the national level in line with the European ones for the sake of a common understanding and a simplified way of conducting trade relations.

12. At the state level, for Ukraine, to define the agrarian sphere not as a subsidy branch, but as a type of management carried out at its own risk by the relevant subject; to make an urgent distinction between activities in the agrarian sector and policy and close relatives; to carry out the removal of any customs, legal barriers to free trade with any 
country in the world; for each inhabitant of the country, to provide information on activities in the agrarian sector, the feasibility of its implementation, natural or organic in order to immediately restore rural and settlement territories, since the said administrative-territorial units are the basis of any country, the basis for ensuring food security, biological, genetic and biodiversity in general (in accordance with current needs and the state of the environment), and, as a result of the integrated impact, the national security of the country us. To introduce into a special updated regulatory legal act in the field of organic matter the mechanism for informing the public, because it is through information, popularization of a certain direction, etc., it is possible to achieve changes in consciousness, change the attitude, if possible so to determine - to make a modern trend that will affect improvement of the environment.

\section{References}

Grain traders offer farmers plundering prices (2019). Available from: https://agronews.ua/node/134557?fbclid=IwAR0laKU 0HpqG0IsMYrR0fHx17pRCvVeCcWRF2GLgpAJG8Smwb3JIcObAU. [Accessed 06.06.2019].

Hot weather in Europe will adjust wheat prices (2019). Available from: https://zernovik.com/news/spekotna-pogoda-v-ievropi-koreguie-cini-napshenicju/?fbclid=IwAR0Qi27lSkoTx4M7GkdRjqw5ll GWgGlt7m08bDO 0ey9qhTFXVrM0AtAg. [Accessed 06.06.2019].

Small producers will be awarded a grant on fruit processing (2018). Available from: https://www.growhow.in.ua/nevelykym-vyrobnykam-nadadut-grant-na-pererobku-fruktiv/. [Accessed 06.06.2019].

Dandelion Business: in two years, you can earn 8,000 euros in profit (2018). Available from: https://willbeua.com/news/biznes-na-kulbabi-za-dva-roki-mozhna-otrimati-8-tisiach-ievropributku 1454/. [Accessed 07.06.2019].

In the Odessa region, the farmer compensated beekeepers for the loss of bee death (2019). Available from: https://stilnyk-ua.blogspot.com/2019/05/blog-post_27.html?fbclid=IwAR2BnxijiBhGm6IP49n8mDA0UN9sIoD D 7O2yLh4X o2qjkLgo8rkwfU8. [Accessed 08.06.2019].

Bees - death can not survive (2019). Available from: https://www.growhow.in.ua/bdzholy-pomerty-nemozhna-

vyzhyty/?fbclid=IwAR2LP1BDcMEL8UuMYa6HYG5FJSTidx3phquLm4HxRQYcW8gNsj5AV 9Y4yuo. [Accessed 08.06.2019].

Americans sentenced to a billion-dollar compensation for the manufacturer of herbicides popular in Ukraine (2019). Available from: https://tsn.ua/svit/hvori-na-rak-amerikanci-zasudili-do-milyardnihkompensaciy-virobnika-populyarnih-v-ukrayini-gerbicidiv-

1347165.html?fbclid=IwAR0575GGN9S-

fx 9BkYvdWaNirTP72Ash2BoQZb7X4Uro55V4JyFXWO1UM. [Accessed 09.06.2019].

Because of the guilt of Monsanto, every second child will be autistic by 2025 (2019). Available from: http://ecology.md/page/po-vine-monsanto-kazhdyj-vtoroj-rebenok-k-2025-godu-budetautistom?fbclid=IwAR0jpPFeXJw8ZrUqQL3aOYZqomwFMmdBIV ApAJjJ73QmtPefiSyw0tlDw. [Accessed 09.06.2019].

The degradation of soils is threatened by the loss of half of the crop yields (2019). Available from: https://agronews.ua/node/130087?fbclid=IwAR0vp1fNGTki0JKEUBjNNe 0Nfwqz2UzJyG4tu jw fDxL4I1ocdAUjkOV04. [Accessed 10.06.2019].

The VRU has adopted a "no-visa" for imported agricultural machinery (2019). Available from: https://agronews.ua/node/132119?fbclid=IwAR3RD2SFKHVuknSTJhT22tvM3XFZDFYGMlo xs1zq5NO9-Xrig0y8Si9xz0Y. [Accessed 10.06.2019].

Ukraine increases agroexport to Japan (2019). Available from: https://bizagro.com.ua/ukraina-narashhivaetagroeksport-v-yaponiyutrofimtseva/?fbclid=IwAR05ThbTrJAKOpfLw86WpDU9TKh5B5JzXfdX1oJjiAaiuRfjlbIHRPtD $\underline{8 \mathrm{PA}}$. [Accessed 10.06.2019]. 
In Poland, one of the most modern organic greenhouses in Europe will be built (2019). Available from: https://agronews.ua/node/134021?fbclid=IwAR1xSn1eLnU5VEPjfyVcHWXliZ9BCx4dlL6nabh as-27uMt1-DbKKAChY3g. [Accessed 10.06.2019].

The main strategy of the UN for the next 10 years is the family farms (2019). Available from: https://agronews.ua/node/131168? fbclid=IwAR1-vowIo-FsQQBN9nS64P9XZOcHB QJ0cVGnT9i0ZDAiwKCPAv-D6SfIo. [Accessed 10.06.2019].

Farmers are asking the authorities to help save the sheep (2019). Available from: https://agronews.ua/node/134640? fbclid=IwAR2YS9yinc7Pbq2Iwxm6C4rzVHubwWvWeWDIW H6V78xxyQ6f8OZOH7GVc. [Accessed 10.06.2019].

Piddubna D.S. (2019). State support of organic farming as a way of preserving natural resources through the prism of international experience: the legal aspect. Scientific Herald of Uzhgorod National University Series Law. Issue 54. Uzhgorod. 2019. 113-120.

Piddubna D.S. (2018). Dotative support in the implementation of organic production by owners of land plots, including land plots (shares). «PARTICULARITĂȚILE ADAPTĂRII LEGISLAȚIEI REPUBLICII MOLDOVA ȘI UCRAINEI LA LEGISLAȚIA UNIUNII EUROPENE» Conferința internațională științifico-practică (2018; Chişinău). 250-253.

Yermolenko V.M. (2019). Some discussion points of the theory of environmental rights. Ecological and legal status of a person and a citizen: retrospective and perspective views: a collection of materials of the international scientific and practical conference (Kiev, May 31, 2019) / Taras Shevchenko National University of Kyiv, Institute of State and Law named after. V.M. Koretsky National Academy of Sciences of Ukraine; for community edit Krasnovoy M.V., Kovalenko T.O. Chernivtsi: Kondratiev A.V. 2019 22-25.

Karakash I.I. (2019). Legal guarantees for the protection and protection of land rights. Collection of materials of the fourth collection of specialists of related departments "Ensuring rights in agrarian, land, ecological and natural resources": materials of the meeting (Odessa, June 6-9, 2019). rec. edit Doctor of Law, associate professor T. Ye. Kharytonova, Ph.D. in Law, Assoc. Kh.A. Hryhorieva. Odessa: Helvetica. 2019. 23-26.

Marchenko Sv. I. (2019). The right to adequate food and the right to freedom from hunger as the basic values of universal principles of law. Ecological and legal status of a person and a citizen: retrospective and perspective views: a collection of materials of the international scientific and practical conference (Kiev, May 31, 2019) / Taras Shevchenko National University of Kyiv, Institute of State and Law named after. V.M. Koretsky National Academy of Sciences of Ukraine; for community edit Krasnovoy M.V., Kovalenko T.O. Chernivtsi: Kondratiev A.V. 2019. 293-296.

Hetman A.P. (2019). Legal principles of human security in the natural environment. Collection of materials of the fourth collection of specialists of related departments "Ensuring rights in agrarian, land, ecological and natural resources": materials of the meeting (Odessa, June 6-9, 2019). rec. edit Doctor of Law, associate professor T. Ye. Kharytonova, Ph.D. in Law, Assoc. Kh.A. Hryhorieva. Odessa: Helvetica. 2019. 13-17.

Kostenko V.O. (2015). Economic and legal support for the use and protection of land: author's abstract. dis ... Candidate lawyer sciences Kharkiv, 2015. Available from: http://dspace.nlu.edu.ua/handle/123456789/9999. [Accessed 19.06.2019].

Romanko Sv. M. (2008). Economic and legal mechanism of providing of ecological safety of agricultural products: author's abstract. dis ... Candidate lawyer sciences Kiev. 2008. 19.

Shulha M.V. (2019). On the issue of land and proprietary powers of local councils. Collection of materials of the fourth collection of specialists of related departments "Ensuring rights in agrarian, land, ecological and natural resources": materials of the meeting (Odessa, June 6-9, 2019). rec. edit Doctor of Law, associate professor T. Ye. Kharytonova, Ph.D. in Law, Assoc. Kh.A. Hryhorieva. Odessa: Helvetica. 2019. 61-64.

Verkhovna Rada of Ukraine (2015). About the civil service. Available from: https://zakon.rada.gov.ua/laws/show/889-19. [Accessed 19.06.2019].

Verkhovna Rada of Ukraine (2013). On the production and circulation of organic agricultural products and raw materials. Available from: https://zakon.rada.gov.ua/laws/show/425-18. [Accessed 19.06.2019]. 
Verkhovna Rada of Ukraine (2018). On Basic Principles and Requirements for Organic Production, Turnover and Marking of Organic Products. Available from: https://zakon.rada.gov.ua/laws/show/2496-19. [Accessed 19.06.2019].

The Ministry of Agrarian Policy works on the legal basis of the organic sector (2019). Available from: https://agronews.ua/node/132144? fbclid=IwAR2I lsyYUkMuZBpGYl0XJ 01ighzm8OuByisWwo9uc8-Q81485NOKaYDo. [Accessed 19.06.2019].

Council Regulation (EC) No 834/2007 (2007). Council Regulation (EC) No 834/2007 of 28 June 2007 concerning organic production and labeling of organic products and repealing Regulation (EEC) No 2092/91. Available from: http://organicstandard.com.ua/files/standards/ua/ec/EU\%20Reg 834 2007\%20Organic\%20Pr oduction UA.pdf. [Accessed 27.06.2019].

Detailed rules. Detailed rules for organic production, labeling and control for the implementation of Council Regulation (EC) No 834/2007 concerning organic production and labeling of organic products. Available

from: http://organicstandard.com.ua/files/standards/ua/ec/EC Reg 8892008 Implementing_Rules UA.pdf. [Accessed 27.06.2019].

The Ministry of Agrarian Policy together with the EU Project is conducting a broad information campaign on state support to farmers (2019). Available from: https://minagro.gov.ua/ua/news/minagropolitiki-spilno-z-proektom-yes-provodyat-shirokuinformacijnu-kampaniyu-shchodo-derzhpidtrimkifermeriv? fbclid=IwAR1WTlpHpiPbK2vQHmDWoYTrldczKvxP5YaT6Qu9xCSKKg655c5cq_c1Dc. [Accessed 27.06.2019].

EU project (2015). EU project "Additional support of the Ministry of Ecology and Natural Resources of Ukraine in the implementation of Sector Budget Support" Quality of the air: a brief description of the EU Directives and timetable for their implementation. Available from: http://www.if.gov.ua/files/uploads/\%D1\%8F\%D0\%BA $\%$ D $1 \% 96 \% \mathrm{D} 1 \% 81 \% \mathrm{D} 1 \% 82 \% \mathrm{D} 1 \% 8 \mathrm{C}$ Air brochure final.pdf. [Accessed 27.06.2019].

Practical guide to the organic exporter to the EU.2 (2017). Available from: http://agritradeukraine.com/images/ATU/ $\% \mathrm{D} 0 \% 9 \mathrm{~F} \% \mathrm{D} 1 \% 80 \% \mathrm{D} 0 \% \mathrm{~B} 0 \% \mathrm{D} 0 \% \mathrm{BA} \% \mathrm{D} 1 \% 82 \% \mathrm{D} 0 \% \mathrm{~B} 8 \% \mathrm{D} 1 \% 8$ $7 \%$ D0 $\%$ BD $\%$ D0 $\%$ B $8 \%$ D0 $\%$ B $9 \%$ D0 $\%$ B $4 \%$ D0 $\%$ BE $\%$ D0 $\%$ B2 $\%$ D $1 \% 96 \%$ D0 $\%$ B $4 \%$ D0 $\%$ BD $\%$ D0\%B8\%D0\%BA \%D0\%BE $\%$ D1 $\% 80 \% \mathrm{D} 0 \% \mathrm{~B} 3 \% \mathrm{D} 0 \% \mathrm{~B} 0 \% \mathrm{D} 0 \% \mathrm{BD} \% \mathrm{D} 1 \% 96 \% \mathrm{D} 1 \% 87 \% \mathrm{D} 0$

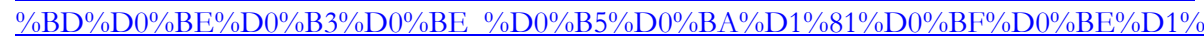
$80 \% \mathrm{D} 1 \% 82 \% \mathrm{D} 0 \% \mathrm{~B} 5 \% \mathrm{D} 1 \% 80 \% \mathrm{D} 0 \% \mathrm{~B} 0 \% \mathrm{D} 0 \% \mathrm{~B} 4 \% \mathrm{D} 0 \% \mathrm{BE} \% \mathrm{D} 0 \% 84 \% \mathrm{D} 0 \% \mathrm{~A} 1 . \mathrm{PDF}$.

[Accessed 27.06.2019].

The Ministry of Agrarian Policy believes that small farmers should be brought under a separate taxation group (2019). Available from: https://www.growhow.in.ua/u-minahropolityky-vvazhaiut-shchomalykh-fermeriv-varto-vyvesty-pid-okremu-hrupuopodatkuvannia/?fbclid=IwAR3tcYlCi8PChOUicheolWSJg5wcobBguQVA2UDF7vJ4Whs2nPm OffcDAeo. [Accessed 28.06.2019].

Poland abolish income tax for young people and will support Ukrainian families (2019). Available from: https://porady.org.ua/polsha-otmenyaet-podokhodnyy-nalog-dlya-molodezhi-i-podderzhit-semiukraincev?fbclid=IwAR1nFWz2rXYLUCyRBpWr7MGrB4eT0I20wkBb1pVbGdB3se TLZ1Qsw oYBRk. [Accessed 28.06.2019].

The EU has published rules for the use of unmanned vehicles, which will take effect in a year (2019). Available from: https://porady.org.ua/es-opublikoval-pravila-ispolzovaniya-bespilotnikovkotorye-vstupyat-v-silu-cherezgod?fbclid=IwAR1MqM6IJTZ4QTaXFNPo9ka63fUBXbGQgmNILKyO8BgvVzxxGj29nimJ Cg . [Accessed 28.06.2019].

State support should have the maximum economic and social impact (2019). Available from: https://minagro.gov.ua/ua/news/vid-derzhavnoyi-pidtrimki-maye-buti-maksimalnijekonomichnij-efekt-olgatrofimceva? fbclid=IwAR3tCau4UPGhiyjougZ8CmiunO4r7u bIrghZHuWmqelizmAceFpK5N0BU. [Accessed 28.06.2019]. 